NBER WORKING PAPER SERIES

\title{
FOREIGN DIRECT INVESTMENT AND DOMESTIC ECONOMIC ACTIVITY
}

\author{
Mihir A. Desai \\ C. Fritz Foley \\ James R. Hines Jr. \\ Working Paper 11717 \\ http://www.nber.org/papers/w11717 \\ NATIONAL BUREAU OF ECONOMIC RESEARCH \\ 1050 Massachusetts Avenue \\ Cambridge, MA 02138 \\ October 2005
}

The statistical analysis of firm-level data on U.S. multinational companies was conducted at the International Investment Division, Bureau of Economic Analysis, U.S. Department of Commerce under arrangements that maintain legal confidentiality requirements. The views expressed are those of the authors and do not reflect official positions of the U.S. Department of Commerce. The authors thank Kevin Hassett, Bill Zeile, and various seminar participants for helpful comments on an earlier draft, and the Division of Research at Harvard Business School for financial support. The views expressed herein are those of the author(s) and do not necessarily reflect the views of the National Bureau of Economic Research.

(C2005 by Mihir A. Desai, C. Fritz Foley, and James R. Hines Jr. All rights reserved. Short sections of text, not to exceed two paragraphs, may be quoted without explicit permission provided that full credit, including (C) notice, is given to the source. 
Foreign Direct Investment and Domestic Economic Activity

Mihir A. Desai, C. Fritz Foley, and James R. Hines Jr.

NBER Working Paper No. 11717

October 2005

JEL No. F230, F210, H250

\begin{abstract}
How does rising foreign investment influence domestic economic activity? Firms whose foreign operations grow rapidly exhibit coincident rapid growth of domestic operations, but this pattern alone is inconclusive, as foreign and domestic business activities are jointly determined. This study uses foreign GDP growth rates, interacted with lagged firm-specific geographic distributions of foreign investment, to predict changes in foreign investment by a large panel of American firms. Estimates produced using this instrument for changes in foreign activity indicate that $10 \%$ greater foreign capital investment is associated with $2.2 \%$ greater domestic investment, and that $10 \%$ greater foreign employee compensation is associated with $4.0 \%$ greater domestic employee compensation. Changes in foreign and domestic sales, assets, and numbers of employees are likewise positively associated; the evidence also indicates that greater foreign investment is associated with additional domestic exports and R\&D spending. The data do not support the popular notion that greater foreign activity crowds out domestic activity by the same firms, instead suggesting the reverse.
\end{abstract}

Mihir A. Desai

Graduate School of Business Administration

Harvard University

Soldiers Field

Boston, MA 02163

and NBER

mdesai@hbs.edu

C. Fritz Foley

Graduate School of Business Administration

Harvard University

Soldiers Field

Boston, MA 02163

and NBER

ffoley@hbs.edu
James R. Hines Jr.

Department of Economics

University of Michigan

611 Tappan Street

Ann Arbor, MI 48109-1220

and NBER

jrhines@umich.edu 


\section{Introduction}

Escalating activity abroad by American companies concerns many observers who fear that outbound foreign direct investment (FDI) reduces employment, capital investment, and tax revenue in the United States, replacing all of these with foreign counterparts that contribute distantly, if at all, to the U.S. economy. An alternative, and rather less common, perspective suggests that growing foreign investment may instead increase levels of domestic activity by making American companies more competitive, thereby increasing the value and magnitude of their domestic operations as they expand globally. Since either of these scenarios is possible in theory, and doubtless there are individual instances of each, empirical analysis is necessary to identify the average effects of changes in foreign activity on the domestic operations of American firms.

This paper evaluates the domestic impact of foreign economic activity by analyzing confidential affiliate-level information on the activities of American manufacturing firms between 1982 and 1999. Use of these data permits individual foreign operations to be matched to the domestic activities of the same firms; as a result, it is possible to measure the extent to which expansions in foreign business activity coincide with changes in domestic activity. There is a strong positive correlation between the domestic and foreign growth rates of multinational firms, which is consistent with the intuition that expanded foreign operations encourage firms to increase their domestic operations, but the fact that foreign and domestic operations are jointly determined makes such evidence inconclusive. Investment and desired output are functions of many variables that influence firm profitability, some of which are inevitably omitted from any empirical analysis, and these omissions may themselves induce positive or negative correlations between foreign and domestic activities. For example, the discovery of a new drug by a pharmaceutical company may be manifest in coincident positive growth of activity both abroad and at home. Alternatively, shifting consumer sentiments might make a consumer products company's wares appear less attractive at home and more attractive abroad, with resulting effects on sales and investment in the two locations.

The use of instrumental variables that predict foreign investment but do not directly affect domestic operations has the potential to identify any effect of foreign investment on 
domestic business activity. The economic performance of foreign economies has promise as such an instrument. Since the locations of foreign investments differ significantly between firms, it is possible to construct firm-specific weighted averages of foreign GDP growth. These firm-specific foreign economic growth rates can be used to generate predicted growth rates of foreign activity that are then employed to explain changes in domestic activity.

This empirical procedure effectively compares two American firms, one whose foreign investments in 1982 were concentrated in Britain, and another whose foreign investments were concentrated in France. As the British economy subsequently grew more rapidly than the French economy, the firm with British operations should exhibit more rapid growth of foreign investment than would the firm with French operations. If the domestic activities of the firm with British operations grow at different rates than the domestic activities of the firm with French operations, it may then be appropriate interpret the difference as reflecting the impact of changes in foreign operations.

The data indicate that foreign GDP growth rates are strong predictors of subsequent foreign investment by American firms. Using weighted GDP growth rates as instruments, second stage equations imply that 10 percent greater foreign capital investment triggers 2.2 percent of additional domestic capital investment, and that 10 percent greater foreign employee compensation is associated with 4.0 percent greater domestic employee compensation. There are similar positive relationships between foreign and domestic changes in sales, assets, and numbers of employees.

The positive association between changes in foreign and domestic activities persists in supplemental specifications designed to address alternative interpretations of the main results. The use of weighted foreign economic growth rates as instruments for changes in foreign investment has the potential to produce misleading results if the foreign investments of firms planning rapid expansion of domestic investment are disproportionately attracted to economies expected to grow rapidly. It is possible to construct economic growth surprises by regressing foreign GDP growth against lagged GDP growth, and to use the residuals from this equation instead of actual GDP growth in explaining foreign investment; this substitution produces very similar results. Another possibility is that industry-specific shocks might be responsible for the 
correlation of foreign and domestic investment growth rates, though the inclusion of industryperiod constants again changes the results very little. If firms export to, and invest in, the same countries, foreign economic growth rates might stimulate domestic economic activity directly. This can be controlled for by including an additional variable equal to export-weighted foreign economic growth, which again does not alter the results. Finally, there are circumstances in which real exchange rate movements that are correlated with economic growth rates might independently influence both foreign and domestic activity, but replicating the analysis with controls for firm-specific changes in foreign exchange rates yields similar answers.

There are several channels through which foreign activities can influence the scope of domestic operations, including cases in which foreign production requires inputs of tangible or intellectual property produced in the home country. The same instrumental variables method used to identify the effect of foreign investment on domestic investment can also be used to identify the effect of foreign investment on other types of domestic activity. The estimates indicate that greater foreign activity is associated with higher exports from American parent companies to their foreign affiliates and is also associated with greater domestic R\&D spending.

The nature of the instrumental variables procedure makes it possible to analyze only firms with prior foreign investments, since it is the geographic distribution of these investments, interacted with GDP growth rates, that predicts changes in foreign operations. Hence this procedure does not measure the impact on domestic activities of establishing foreign operations for the first time. Furthermore, the analysis is inherently partial equilibrium in nature, comparing changes in one firm against changes in another at the same time. Possible policy reforms, including tax and regulatory changes, that would encourage or discourage foreign investment, affecting all firms in the economy at the same time, would also likely influence factor prices and output prices in a way that might indirectly influence levels of domestic economic activities. The empirical work in this paper considers reactions by individual firms to changes in their own foreign operations, providing an important part, though not all, of the evidence necessary to evaluate the impact of the foreign operations of American firms on total U.S. domestic economic activity. 
Previous studies report mixed results in analyzing the impact of foreign operations on domestic economic activity. Lipsey (1995) analyzes a cross-section of American multinational firms, reporting a mild positive correlation between foreign production and domestic employment levels. Stevens and Lipsey (1992) analyze the investment behavior of seven multinational firms, concluding that investments in different locations substitute for each other due to costly external financing. The absence of compelling instruments that satisfy the necessary exclusion restrictions complicate the interpretation of this evidence, a problem that likewise appears in studies of aggregate FDI and domestic investment. Feldstein (1995) analyzes decade-long averages of aggregate FDI and domestic investment in OECD economies, reporting evidence that direct investment abroad reduces domestic investment levels. Devereux and Freeman (1995) come to a different conclusion in their study of bilateral flows of aggregate investment funds between seven OECD countries, finding no evidence of tax-induced substitution between domestic and foreign investment, and Desai, Foley and Hines (forthcoming) report time series evidence that foreign and domestic investment are positively correlated for American firms. Blonigen (2001) investigates the related question of whether foreign production by multinationals is a substitute or complement for exports, finding evidence for both effects. The effect of foreign operations on the domestic activities of multinational firms therefore remains an open question. ${ }^{1}$

Much of the recent theoretical and empirical work on multinational firms emphasizes alternative motivations for foreign direct investment (either "horizontal" or "vertical" motivations $^{2}$ ) or the reasons why alternative productive arrangements (whole ownership of foreign affiliates, joint ventures, exports or arms-length contracts ${ }^{3}$ ) are employed. Specifically, several recent papers, including Hummels, Ishii and Yi (2001), Yi (2003) and Hanson, Mataloni and Slaughter (forthcoming) emphasize the importance of vertical specialization to international

\footnotetext{
${ }^{1}$ Several studies, including Brainard and Riker (1997), Riker and Brainard (1997), Slaughter (2000), Feenstra and Hanson (1996, 1999) and Harrison and McMillan (2004) have emphasized the link between foreign activities and domestic wages and employment. Additionally, Blonigen and Wilson (1999) investigate the role of demand by multinational firms in determining variations in the measured substitutability of foreign and domestic goods. ${ }^{2}$ The horizontal FDI view represents FDI as the replication of capacity in multiple locations in response to factors such as trade costs, as in Markusen $(1984,2002)$. The vertical FDI view represents FDI as the geographic distribution of production globally in response to the opportunities afforded by different markets, as in Helpman (1984).

${ }^{3}$ Antràs (2003), Antràs and Helpman (2004), Desai, Foley and Hines (2004), Helpman, Melitz and Yeaple (2004) and Feenstra and Hanson (2005) analyze the determinants of alternative foreign production arrangements.
} 
trade patterns and the expansion strategies of multinationals firms. The findings of this research - that multinational firms exhibit high degrees of integrated production - are consistent with sizeable effects of foreign operations on domestic activity. Much of current U.S. tax policy is based on the premise that greater foreign business activity comes at the cost of reduced domestic activity. Evidence to the contrary suggests that the conceptual framework used to evaluate policies might be due for revision, as discussed in Desai and Hines (2003).

Section 2 of the paper sketches a simple framework for the analysis of interactions between the domestic and foreign operations of multinational firms. Section 3 describes the available data on American direct investment abroad. Section 4 presents empirical evidence of the determinants of foreign investment levels by American firms, and the impact of foreign investment on economic activity in the United States. Section 5 discusses the implications of the empirical evidence, and section 6 is the conclusion.

\section{The Relationship Between Foreign and Domestic Operations of Multinational Firms}

The effect of foreign operations on the domestic operations of multinational firms turns on production and cost considerations that might take any of a number of forms. One possibility is that a multinational firm's total worldwide production level is approximately fixed, being determined by market conditions and government policies. Given that foreign and domestic factors of production are conditional substitutes, any additional foreign production then necessarily reduces domestic production, hence foreign and domestic investment levels will be negatively correlated. Alternatively, the level of total production might not be fixed, but instead responsive to profit opportunities, the value of which is affected by foreign and domestic production considerations. In such a framework it is possible that greater foreign activity reduces costs and raises the return to domestic production, stimulating domestic factor demand and domestic output. Firms might, for example, find that foreign operations provide valuable intermediate inputs at low cost, or that foreign affiliates serve as ready buyers of tangible and intangible property produced in the United States.

\subsection{Framework for Analysis}


In order to distinguish these cases it is useful to consider the impact of foreign activities on domestic factor demands through effects on the productivity and costs of domestic operations. It simplifies matters to consider the case in which the firm is indifferent to the location of its output, as would be true if the final product is freely traded and tax differences are immaterial. Total output is given by the function $Q(D, F, x, z)$, in which $\mathrm{D}$ is the level of domestic input, $F$ is foreign input, $x$ consists of factors that influence domestic production, and $z$ represents factors that influence foreign production. Total firm costs are given by $\lambda(D, F, x, z)$. Profits $(\pi)$ equal the difference between the value of output (whose price is normalized to unity) and total production costs:

$$
\pi=Q(D, F, x, z)-\lambda(D, F, x, z)
$$

Since firms choose domestic and foreign inputs jointly to maximize $\pi$, it is necessary to specify carefully how foreign activities influence domestic operations. Consider the impact of a small change in foreign inputs induced by variation in the specific foreign factor (z), such as might occur if there were changes in foreign government regulations or local costs. Then the domestic reaction to the foreign input change can be denoted $\frac{d D}{d F}$, which, as long as $z$ does not affect $D$ directly but only through its impact on $F$, is a valid indicator of the domestic production response to foreign shocks.

The first-order condition that characterizes the firm's profit-maximizing choice of domestic inputs is:

$$
\frac{\partial Q(D, F, x, z)}{\partial D}=\frac{\partial \lambda(D, F, x, z)}{\partial D}
$$

The variable $z$ is defined so that a small change does not affect the derivatives on either side of equation (2), ${ }^{4}$ specifically that $\frac{\partial^{2} Q}{\partial D \partial z}=\frac{\partial^{2} \lambda}{\partial D \partial z}=0$. It follows from (2) that a small change in the factors (z) that influence foreign profitability induces changes in factor demands that satisfy:

\footnotetext{
${ }^{4}$ The specification requires that the production function take a separable form such as $Q(D, F, x, z)=Q_{1}(D, F)+Q_{2}(D, x)+Q_{3}(F, z)$, and that the cost function have a similarly separable nature.
} 


$$
\frac{\partial^{2} Q}{\partial D^{2}} \frac{d D}{d F} \frac{d F}{d z}+\frac{\partial^{2} Q}{\partial D \partial F} \frac{d F}{d z}=\frac{\partial^{2} \lambda}{\partial D^{2}} \frac{d D}{d F} \frac{d F}{d z}+\frac{\partial^{2} \lambda}{\partial D \partial F} \frac{d F}{d z},
$$

which in turn implies:

$$
\frac{d D}{d F}=-\frac{\frac{\partial^{2} Q}{\partial D \partial F}-\frac{\partial^{2} \lambda}{\partial D \partial F}}{\frac{\partial^{2} Q}{\partial D^{2}}-\frac{\partial^{2} \lambda}{\partial D^{2}}} .
$$

Equation (4) identifies the effect of production and cost considerations on the relationship between foreign and domestic operations, ${ }^{5}$ including cases that are consistent with the common intuition that foreign inputs substitute one-for-one for domestic inputs. If foreign and domestic inputs are perfect substitutes in production $\left(\frac{\partial^{2} Q}{\partial D \partial F}=\frac{\partial^{2} Q}{\partial D^{2}}\right)$ and also perfect substitutes in determining costs $\left(\frac{\partial^{2} \lambda}{\partial D \partial F}=\frac{\partial^{2} \lambda}{\partial D^{2}}\right)$, then $\frac{d D}{d F}=-1$, and greater foreign inputs displace domestic inputs. If foreign and domestic inputs are perfect substitutes in production, and costs are separable and linear in foreign and domestic inputs $[\lambda(D, F, x, z)=a D g(x)+b F h(z)]$, it is again the case that $\frac{d D}{d F}=-1$. More generally, the combination of linear production costs, output that exhibits decreasing returns to domestic factors, and any kind of substitutability in production between foreign and domestic inputs $\left(\frac{\partial^{2} Q}{\partial D \partial F}<0\right)$ produces outcomes in which foreign and domestic inputs are substitutes, since $\frac{d D}{d F}<0$.

There are, however, many realistic cases in which the greater use of foreign inputs might stimulate additional demand for domestic inputs. For example, if output is additively separable

\footnotetext{
${ }^{5}$ It is noteworthy that $d D / d F$ in equation (4) is specific to consideration of changes in $z$. A change in $x$ generates changes in domestic inputs, and induced changes in foreign inputs $(d F / d D)$ that are not symmetric with the effects of $z$, in that it need not be the case that $d D / d F$ equals $1 /(d F / d D)$. Symmetry is a property of Hicksian (price) crosselasticities, the estimation of which requires data on prices; whereas these are quantity cross-elasticities. Samuelson (1974) analyzes the properties of alternative measures of input substitutability and complementarity, including hybrid price and quantity measures closely related to that in equation (4).
} 
into foreign and domestic production $\left[Q(D, F, x, z)=Q_{1}(D, x)+Q_{2}(F, z)\right]$, and firms face rising costs of domestic inputs $\left(\frac{\partial^{2} \lambda}{\partial D^{2}}>0\right)$, but higher levels of foreign inputs reduce the marginal cost of domestic production $\left(\frac{\partial^{2} \lambda}{\partial D \partial F}<0\right)$, then greater foreign activity stimulates additional domestic activity. Foreign inputs would have this effect on domestic costs if, for example, ownership of foreign assets makes a domestic firm a better credit risk, thereby reducing its cost of borrowing to finance domestic investment. Alternatively, if costs are separable and linear in foreign and domestic inputs, but foreign and domestic inputs satisfy a type of production complementarity $\left(\frac{\partial^{2} Q}{\partial D \partial F}>0\right)$, then greater foreign production stimulates higher levels of domestic activity.

In order to illustrate how the effects of foreign operations on domestic operations would be manifest in specific settings, it is useful to consider a firm with a constant elasticity of substitution production function:

$$
Q(D, F, x, z)=a\left[b D^{-\beta}+c F^{-\beta}\right]^{-h}
$$

in which $\eta \equiv \frac{1}{1+\beta}$ is the elasticity of substitution between $D$ and $F, h$ is the (positive) degree of output homogeneity, and $a, b$, and $c$ are positive constants. With linear costs, $\frac{\partial^{2} \lambda}{\partial D \partial F}=\frac{\partial^{2} \lambda}{\partial D^{2}}=0$, and applying the formula (4) to the production function (5) yields:

$$
\frac{d D}{d F}=\frac{c(h+\beta) \frac{D}{F}}{c(1+\beta)+(1-h) b\left(\frac{D}{F}\right)^{-\beta}} .
$$

Some special cases are clear from examination of (6). If the production function is linear $(\beta=-1)$, then $\frac{d D}{d F}=-\frac{c}{b}$, a negative constant. If production exhibits constant returns to scale 
$(h=1)$, then $\frac{d D}{d F}=\frac{D}{F}$. Likewise if the production function takes the Leontief form $(\lim \beta \rightarrow \infty)$, then $\frac{d D}{d F}=\frac{D}{F}$; and if the production function is Cobb-Douglas $(\lim \beta \rightarrow 0)$, then $\frac{d D}{d F}=\frac{c h}{[c+(1-h) b]} \frac{D}{F}$. This simple exercise demonstrates that common specifications of production and cost functions yield very different theoretical predictions about the nature and sign of the effect of foreign activity on domestic activity.

\subsection{Empirical Strategy}

Estimating the effect of foreign investment on domestic investment entails calculating average effects for a large and possibly heterogeneous sample. The relationship expressed by equation (6) suggests that an appropriate linearization can be obtained by dividing both sides of (6) by $(D / F)$, producing:

$$
\frac{d D}{d F} \frac{F}{D}=\frac{c(h+\beta)}{c(1+\beta)+(1-h) b\left(\frac{D}{F}\right)^{-\beta}}
$$

Equation (7) implies that the elasticity of domestic investment with respect to induced changes in foreign investment is a function of several constants and the ratio $\left(\frac{D}{F}\right)^{-\beta}$, with $\lim \beta \rightarrow 0$ corresponding to the Cobb-Douglas function.

Taking the right side of (7) to be approximated by a simple constant corresponding to the average value of this ratio for all firms in the sample, it follows that $\frac{d D}{d F} \frac{F}{D}=\gamma$, in which the constant $\gamma$ is the elasticity of domestic activity with respect to foreign activity. This specification implies that $D$ and $F$ are related by $D=k F^{\gamma}$, in which $k$ is a constant. It then follows that $\frac{d D}{d F}$, evaluated at points $(\tilde{D}, \tilde{F})$, is given by: 


$$
\frac{d D}{d F}=\gamma \frac{\tilde{D}}{\widetilde{F}} .
$$

In order to estimate the relationship expressed by equation (8) it is necessary to select the point $(\tilde{D}, \tilde{F})$ around which to take the linear approximation to $\frac{d D}{d F}$. In evaluating changes it is natural to use start of period values of $D$ and $F$ for $(\tilde{D}, \tilde{F})$, but the empirical work in the paper instead uses the average of start of period and end of period values. Two considerations motivate this choice. The first is that periods represent intervals between BEA benchmark surveys, which last five or seven years, during which firms may experience many changes. The lengthy interval suggests that average values of $D$ and $F$, rather than starting values, offer the most reliable benchmark ratio of domestic to foreign assets. The second consideration is that observations of individual firms can exhibit extreme volatility in domestic and foreign growth rates measured using start of period values of $D$ and $F$, with a small number of individual firm observations capable of dominating a regression sample. Linearizing the expression for $\frac{d D}{d F}$ around $(\tilde{D}, \tilde{F})$ chosen as an average of start of period and end of period values of $D$ and $F$ greatly reduces the impact of outliers, thereby producing more reliable estimates. ${ }^{6}$

\section{3. $\quad$ Instrumental Variables}

Simple OLS regressions are capable of producing estimates of the impact of foreign investment on domestic investment, but obtaining reliable estimates of the sign and magnitude of $\frac{d D}{d F}$ requires addressing concerns about endogeneity. Unobserved factors could induce either a positive or negative correlation in OLS regressions of changes in the use of domestic inputs on changes in the use of foreign inputs. For example, if a firm's research efforts produce innovations that improve productivity both at home and abroad, then both foreign and domestic operations might expand, but not because changes in foreign inputs are responsible for changes in domestic inputs. Alternatively, international price movements, or changes in consumer tastes,

\footnotetext{
${ }^{6}$ Construction of growth rates around averages of start and end of period values has become standard procedure in the analysis of firm-level job flows, as in Davis, Faberman, and Haltiwanger (forthcoming). Tornqvist, Vartia, and
} 
might make the product that a firm produces at home less marketable, while making the somewhat different product produced by the firm's foreign affiliates more marketable. In order to evaluate the effects of foreign activity on domestic operations it is therefore necessary to employ an instrumental variables approach. This requires identifying economic factors that influence levels of foreign activity, that are not themselves directly controlled by American investors, and that might influence levels of domestic activity only through their impact on foreign activity.

Economic growth rates in foreign countries have the potential to serve as appropriate instruments for changes in levels of foreign investment. Rapid economic growth is associated with high investment levels by local firms, presumably reflecting that marginal $q$, the ratio of the market value of capital to its replacement cost, is unusually high. American firms with local operations are subject to many of the same market influences as are local firms, and therefore these firms are likely to expand their own investments when aggregate $q$ is high.

As an empirical matter, American firms with operations in rapidly growing foreign economies expand their foreign operations at faster paces than do American firms whose foreign operations are concentrated in countries with slowly growing economies. This pattern corresponds to the simple insight that rapid economic growth, and associated rising $q$, provides the greatest profit opportunities to firms with significant previous local exposure. There are at least two possible channels for this effect, the first being that local experience is a valuable base from which business operations can be expanded when opportunities grow with the local economy. The second channel is that prior local experience is a proxy for unmeasured firm attributes that make a firm well positioned to earn profits in some countries and not in others. When an economy's $q$ rises, then firms with attributes that match them well to the country find that their profit opportunities expand at the same time.

The empirical strategy takes a firm's initial distribution of activity among foreign countries to be exogenous from the standpoint of subsequent changes in domestic business activity. Foreign economies grow at different rates, and with them grow levels of economic activity by U.S.-owned affiliates. The first stages of the regressions use the fact that firms differ 
in their initial distributions of foreign economic activity to predict different growth rates of subsequent activity, based on differences in the average GDP growth rates of the countries in which their activities were initially concentrated. These predicted growth rates then become the independent variables in second stage equations used to explain changes in domestic business operations.

In order to serve as a valid instrument it is necessary that the average GDP growth rate of foreign countries in which a firm invests affects its domestic operations only by influencing the level and character of its foreign operations. This restriction cannot be directly tested, but reasonable specifications of production processes within multinational firms imply that by far the most likely channel by which foreign economic prosperity affects firms with local operations is by affecting local operations. Three scenarios in which the instrument would be invalid are worth noting; these are addressed by the empirical tests below. First, parent firms that are trying to grow quickly may invest in countries that expected to grow quickly in the future. This possibility can be addressed by conducting tests using measures of unexpected growth as instruments. Second, the activities of certain industries might be concentrated in certain countries, and domestic and foreign operations might experience common shocks. For example, if most of the foreign operations of electronic component manufacturing parents were located in Asia, a productivity shock to the industry could be associated with high growth in Asia, and it could have a direct effect on the growth of parent firms in the industry. This possibility can be addressed by including fixed effects that are specific to individual industries in particular periods in the main specifications of interest. Third, firms might export to the same foreign countries in which they invest, in which case foreign economic growth might stimulate exports and thereby domestic operations directly. This possibility can be addressed by including an independent variable equal to export-weighted foreign economic growth.

It is also possible that foreign investment by American firms affects local GDP growth rates, making foreign GDP growth rates inadmissible as instruments in explaining foreign investment. This effect is, however, likely to be very small in magnitude except for a certain number of small countries, principally tax havens, that draw disproportionate volumes of U.S.

measure to alternatives including log changes and growth rates calculated relative to initial values. 
investment. ${ }^{7}$ Since the empirical work presented in the paper uses average foreign GDP growth rates weighted by investment levels, this consideration is very unlikely to contaminate the estimated results.

\section{Data and descriptive statistics}

The empirical work presented in section 4 is based on the most comprehensive and reliable available data on the activities of American multinational firms. The Bureau of Economic Analysis (BEA) Benchmark Surveys of U.S. Direct Investment Abroad in 1982, 1989, 1994 and 1999 provide a panel of data on the financial and operating characteristics of U.S. multinational firms. ${ }^{8}$ In order to limit the heterogeneity of the sample, observations are restricted to American firms with parent companies in manufacturing industries (as defined in the BEA survey using a classification that corresponds almost exactly to SIC codes 20-39). In each of the four benchmark years, all affiliates with sales, assets, or net income in excess of certain size cutoffs of no more than $\$ 7$ million in absolute value, and their parents, were required to file extensive reports. Measures of aggregate foreign activity of individual firms are obtained by summing measures of activity across the firm's foreign affiliates. The surveys collect sufficient information to quantify domestic and foreign assets, net property, plant and equipment, employment compensation, employment, R\&D spending, exports and total sales. ${ }^{9}$

The BEA collects identifiers linking parents and affiliates through time, thereby permitting the calculation of changes in domestic and foreign input use. Growth rates are computed as ratios of changes in activity between benchmark years to averages of beginning and ending period levels of activity. Since the data include four benchmark survey years - 1982, 1989, 1994, and 1999 - it is possible to calculate changes in this normalized measure for at most three periods. As the analysis considers changes only, firms that initiate or terminate global activities between benchmark years are not part of the analysis.

\footnotetext{
${ }^{7}$ For an analysis of the effect of foreign direct investment on GDP growth rates of small tax havens, see Hines (2005).

${ }^{8}$ The International Investment and Trade in Services Survey Act governs the collection of the data and the Act ensures that "use of an individual company's data for tax, investigative, or regulatory purposes is prohibited." Willful noncompliance with the Act can result in penalties of up to $\$ 10,000$ or a prison term of one year. As a result of these assurances and penalties, BEA believes that coverage is close to complete and levels of accuracy are high.

${ }^{9}$ Parent company equity and debt investments in foreign affiliates are subtracted from the parent's total assets in order to avoid spurious correlations between changes in foreign assets and changes in domestic assets.
} 
Appendix Table 1 presents data on changes in net foreign property, plant and equipment investment of U.S. multinationals, decomposing these changes into the growth of surviving firms, entry by new firms, and capital reductions due to exit by firms that were previously part of the sample. The change in foreign activity attributable to the growth of surviving parents is considerably larger than is the change due to net entry and exit of parents in each of the three periods covered by the data. For example, between 1982 and 1989, the foreign affiliates of surviving parents accumulated $\$ 82.2$ billion of additional property, plant and equipment, a figure that exceeds the $\$ 72.7$ billion net accumulation of all American-owned foreign affiliates during this period. Between 1989 and 1994, the foreign affiliates of surviving parents accumulated $\$ 80.0$ billion of new property, plant and equipment, out of a total of $\$ 88.2$ billion. A substantial fraction of the exit that occurs is the consequence of some U.S. multinational firms buying others. Of the $\$ 24.6$ billion of 1982 foreign net property, plant and equipment owned by firms that leave the sample in between 1982 and 1989, \$15 billion is accounted for by firms that are acquired by other U.S. multinationals.

Table 1 presents means, medians, and standard deviations of variables used in the regressions that follow. The instrumental variables procedure uses foreign GDP growth rates, which are calculated by dividing changes (between benchmark years) in the gross domestic product per capita of affiliate host countries by the average of beginning and ending period values. ${ }^{10}$ These country growth rates are aggregated using weights equal to a firm's beginning of period affiliate net property, plant and equipment in each country. To control for the possibility that GDP growth rates affect domestic levels of activity by influencing parent exports to final consumers abroad, some regressions include as an independent variable GDP growth rates weighted by a parent company’s beginning of period exports to unrelated parties. Some regressions also include changes in real exchange rates, which are computed using nominal exchange rates taken from Heston, Summers, and Aten (2002) and measures of inflation from the IMF's International Financial Statistics database; the real exchange rate movement is defined to equal the ratio of the change in the dollar-equivalent real exchange rate to the average of this rate at the beginning and end of period. Firm-specific exchange rate changes equal the product of

\footnotetext{
${ }^{10}$ Per capita gross domestic product is the CGDP variable reported by Heston, Summers and Aten (2002), representing incomes adjusted for purchasing power and reported in current dollars.
} 
these real exchange rate changes and weights equal to beginning of period affiliate net property plant and equipment in each country.

\section{The Relationship Between Multinational Foreign and Domestic Activity}

The simple correlation of changes in foreign and domestic activity is clear from Figure 1, which presents a scatter plot of foreign and domestic sales growth rates for multinational firms in the sample. ${ }^{11}$ As in the regression analysis, foreign growth rates are defined as the ratio of the change in a measure of foreign activity between benchmark years to the average of its values in these years; and domestic growth rates are similarly defined. The upward sloping relationship between foreign and domestic sales growth in Figure 1 suggests a positive correlation between growth rates of foreign and domestic economic activity that is investigated further below.

\subsection{OLS Specifications}

Table 2 presents estimated coefficients from OLS specifications explaining changes in the domestic activities of parent companies as functions of changes in their foreign activities. All specifications include period fixed effects, and the standard errors correct for clustering at the parent company level. $^{12}$ The 0.1994 coefficient reported in column 1 of Table 2 indicates that 10 percent higher foreign net property, plant and equipment growth is associated with 2.0 percent higher domestic net property, plant and equipment growth by parent companies. Asset accumulation displays a similar pattern, the 0.2953 coefficient reported in column 2 implying that 10 percent foreign asset growth is associated with three percent domestic asset growth. The regressions reported in columns three and four consider changes in labor demand. The 0.2581 coefficient reported in column three indicates that 10 percent higher foreign employment compensation is associated with a 2.6 percent greater domestic employment compensation. The 0.2448 coefficient reported in column four similarly implies that 10 percent higher numbers of foreign employees is associated with 2.5 percent higher numbers of domestic employees. Finally, the 0.3181 coefficient reported in column five indicates that 10 percent greater foreign sales are associated with 3.2 percent greater domestic sales, a confirmation of the visual

\footnotetext{
${ }^{11}$ Foreign sales refers to the sales of a firm's foreign affiliates, regardless of the destination of those sales, and domestic sales refers to the sales of a firm's domestic operations, regardless of the destination of those sales.

${ }^{12}$ Information is missing for some firms in certain years, which is why sample sizes vary between specifications in Table 2.
} 
relationship apparent in Figure 1. Across all of these measures of multinational firm activity, the OLS analysis suggests that increased foreign activity is associated with greater domestic activity.

\subsection{Instrumental Variables Specifications}

The instrumental variables approach outlined above relies on the ability of foreign economic growth rates to explain changes in foreign activity levels of American multinational firms. Table 3 presents the results of regressions of growth rates of foreign activity on firmspecific weighted averages of foreign economic growth rates, the weights corresponding to beginning of period distributions of foreign property, plant, and equipment. Growth rates are defined as in Table 2, all specifications include period fixed effects, and the standard errors correct for clustering at the parent level.

The results indicate that the economic performance of foreign economies significantly influences the foreign activity of American multinational firms. The 1.7802 coefficient reported in column one indicates that two percent faster annual average GDP growth in countries in which a firm invests is associated with 3.6 percent faster growth of affiliate net property, plant and equipment. Similar results appear in the regressions reported in columns 2-5, whose coefficients imply that two percent faster annual GDP growth is associated with 2.9 percent greater foreign asset accumulation, 2.5 percent greater foreign employee compensation growth, 1.4 percent greater foreign employment growth, and 3.2 percent greater foreign sales growth.

Foreign economic growth is associated with greater levels of foreign activity by American firms either because economic growth increases the value of the foreign output of American firms or because foreign economic growth coincides with reduced real input costs due to productivity gains or other changes. While it is difficult to distinguish output from cost effects on the return to foreign investment, it is possible to identify the impact of foreign GDP growth on local and export sales by foreign affiliates, and the effects of GDP growth on sales to related and unrelated parties. Such an exploration also addresses concerns that the instrumental variables analysis below is only relevant for certain types of foreign investments - for example, those that serve local markets. 
Appendix Table 2 presents regressions in which the dependent variables are changes in foreign affiliate sales, distinguished by destination. The 1.7577 coefficient in column one indicates that two percent faster foreign GDP growth is associated with 3.5 percent greater sales by foreign affiliates to local markets, while the 0.8786 coefficient in column two suggests that the same two percent faster foreign GDP growth is associated with 1.8 percent greater export sales by foreign affiliates. Foreign economic growth stimulates greater sales by foreign affiliates to local markets, but also greater activity that foreign affiliates direct at other markets. An analogous pattern appears in the regressions presented in columns three and four. The 1.6313 and 1.0964 coefficients reported in columns three and four indicate that two percent faster GDP growth is associated with 3.3 percent greater affiliate sales to unrelated parties, and 2.2 percent greater affiliate sales to related parties. Hence it appears that only part of the effect of foreign GDP growth on foreign investments stems from provision of output to serve customers in local markets, the remainder reflecting a variety of considerations that also influence the desirability of foreign investment. $^{13}$

Table 4 presents estimated coefficients from instrumental variables regressions in which predicted values of changes in foreign activity (based on coefficients drawn from the regressions presented in Table 3) are used to explain changes in domestic capital and labor demand. The dependent variables in the regressions presented in Table 4 are growth rates of domestic net property, plant and equipment and employee compensation; results for assets, numbers of employees, and sales are presented in Appendix Table 4. All specifications include period fixed effects, and the standard errors allow for clustering at the parent level. The 0.2174 coefficient in column one of Table 4 indicates that 10 percent greater accumulation of foreign property plant and equipment, as predicted by host country GDP growth, is associated with 2.2 percent growth of domestic net property plant and equipment. This estimated effect is quite similar to that

\footnotetext{
${ }^{13}$ The regressions presented in Appendix Table 3 offer additional evidence that foreign production directed at local sales constitutes only part of the effect of foreign GDP growth on foreign investment. The first two of these regressions introduce a new dummy variable that takes the value one for the half of the sample whose foreign affiliates concentrate their sales in local markets, and zero for firms whose foreign affiliates' sales are less directed at local markets. The -0.2985 and -0.3349 coefficients in columns one and two are statistically insignificant. If anything, their sign suggests that greater foreign economic growth actually has a smaller impact on foreign capital and labor expenditures for firms more focused on selling to local markets. The regressions reported in columns three and four add a new dummy variable equal to one for firms whose foreign affiliates sell predominantly to related parties. Again, the 0.3072 and 0.2713 coefficients reported in columns three and four are statistically
} 
implied by the OLS regression reported in column 1 of Table 2, and, for a firm with the sample median 6.75 ratio of domestic to foreign property, plant and equipment, implies that $\$ 10$ of additional foreign capital is associated with $\$ 14.7$ of additional domestic capital. There is no indication that firms accumulating capital assets in their foreign affiliates do so at the expense of domestic capital accumulation; instead, greater use of foreign capital appears to stimulate greater use of domestic capital.

The dependent variable in the regression reported in the second column of Table 4 is the growth rate of domestic employee compensation; the 0.4046 coefficient indicates that greater use of foreign labor is associated with greater demand for domestic labor. This estimated effect is somewhat larger than that implied by the 0.2581 OLS coefficient presented in column 3 of Table 2, though the two are statistically indistinguishable. For a firm with the sample median 4.56 ratio of domestic to foreign employee compensation, the IV estimate implies that $\$ 10$ of additional foreign wages is associated with $\$ 18.4$ of additional domestic wages.

The regressions presented in columns 1 and 2 of Table 4 include foreign and domestic factor changes measured as growth rates. An alternative approach, used in the regressions reported in columns 3 and 4, is to linearize the relationship as in equation (6), specifying changes in levels of domestic factor use as functions of changes in levels of foreign factor use. The dependent variable in the regression reported in the third column of Table 4 is the change in domestic net property, plant and equipment between two benchmark years. Predicted values of changes in foreign net property, plant and equipment are obtained from a first stage regression similar to that presented in column 1 of Table 3, but in which the change in foreign net property, plant and equipment is measured in levels, and weighted foreign economic growth rates are interacted with beginning of period foreign net property, plant and equipment to generate estimated foreign changes. The 0.6720 coefficient in column three implies that $\$ 10$ of additional foreign capital accumulation is associated with $\$ 6.7$ of additional domestic capital accumulation, which is somewhat smaller than the effect implied by the estimate in column one for firms with median ratios of domestic to foreign capital. The regression reported in column 4 of Table 4 estimates the effect of changes in levels of foreign wages on changes in levels of domestic 
wages, using the interaction of beginning of period foreign wages interacted with foreign economic growth rates as instruments for foreign wage changes. The 1.1128 coefficient in column 4 indicates that $\$ 10$ of additional foreign employee compensation is associated with $\$ 11.1$ of additional domestic employee compensation, though this effect is not statistically significant, and again somewhat smaller than the effect implied by the coefficient in column two for a firm with the median ratio of domestic to foreign wages.

\subsection{Alternative Specifications}

If firms with rapidly growing domestic activities choose to locate their foreign operations in relatively high growth economies, the results in Table 4 may not accurately reflect the influence of higher foreign growth rates on domestic factor demands. In order to evaluate this possibility, the regressions presented in the first two columns of Table 5 use measures of unexpected host country growth as instruments. Specifically, these instruments are computed by taking residuals from a regression of GDP growth on its own lag, then weighting these residuals using firm specific weights that correspond to beginning of period levels of net property, plant and equipment. The regressions reported in columns 1 and 2 of Table 5 are run on the same sample as that used in the regressions reported in columns 1 and 2 of Table 4, and the estimated coefficients are quite similar ( 0.2132 and 0.2174 in the case of property, plant and equipment; 0.3999 and 0.4046 in the case of wages), suggesting that it is the unpredictable component of GDP growth that is responsible for the results appearing in Table 4.

Some countries may be dominated by small numbers of industries, in which firms experience common shocks that affect their foreign and domestic activities; in such cases, the foreign and domestic investments of the firms, and the GDPs of the countries in which they invest, would all be positively correlated. In order to guard against the possibility that this phenomenon is important enough to drive the results, the regressions reported in columns three and four of Table 5 include fixed effects specific to each two-digit parent industry for each time period in the data. The estimated coefficients are again very similar ( 0.2560 and 0.2174 in the case of property, plant and equipment; 0.3948 and 0.4046 in the case of wages) to those in Table 4. 
Another potential concern with the identification strategy used in the instrumental variables regressions is that firms with considerable foreign direct investment in a country might also export significant amounts of its final product from the U.S. to end customers in the same country. If this were the case, local GDP growth would be an invalid instrument, since high foreign economic growth would directly stimulate domestic investment to meet export demand. The regressions presented in Table 6 address this possibility by including as an independent variable a measure of foreign GDP growth weighted by beginning of period firm exports to unrelated parties, constructed from BEA data that identify the destination of each firm's U.S. exports to unrelated parties. Since not all parents are exporters, the use of trade share data reduces sample sizes somewhat, but, as the regressions reported in columns one and two of Table 6 illustrate, the inclusion of trade-weighted GDP growth rates has very little impact on the estimated effects of foreign capital accumulation and wage growth. Ten percent faster foreign capital accumulation is associated with 2.6 percent faster domestic capital accumulation in the regression reported in column one, and ten percent faster foreign wage growth is associated with 3.8 percent faster domestic wage growth in the regression reported in column two. The estimated direct effects of trade-weighted foreign GDP growth are negligible in both regressions.

It is also possible that real exchange rate movements that are associated with differences in GDP growth rates might influence relative prices in a way that directly affects factor demands by multinational firms. The regressions reported in columns three and four of Table 6 address this concern by including measures of real exchange rate changes weighted by a firm’s distribution of property, plant and equipment at the beginning of each period. Estimated coefficients on the exchange rate variable are not significant in either regression, whereas inclusion of the exchange rate variable increases the estimated magnitude of the effects of foreign investment and wage growth on domestic activity. The estimated 0.3479 coefficient in column three implies that 10 percent greater foreign investment is associated with 3.5 percent greater domestic investment, and the 0.4855 coefficient in column four implies that 10 percent greater foreign wage growth is associated with 4.9 percent greater domestic wage growth.

The merger and acquisition activities of multinational firms raise the possibility that the estimated impact of foreign investment on domestic investment might reflect what happens when one U.S. multinational firm buys another, thereby simultaneously acquiring the target's domestic 
and foreign assets. If this acquisition activity is most prevalent among firms with foreign affiliates located in high growth countries, then it could be responsible for the pattern that is apparent in the data. In such cases the estimated effect of foreign investment on domestic investment may offer a misleading picture of changes in factor demands, since acquisitions may entail purchasing bundles of foreign and domestic assets that are not what the acquirer would otherwise desire. The regressions presented in the first four columns of Table 7 address this potential problem by removing from the sample observations of parent companies that acquire other American parent companies or divisions of other parents. ${ }^{14}$

Columns 1 and 2 of Table 7 present OLS specifications of regressions run on the restricted sample of firms, and include controls for trade-weighted GDP growth and real exchange rate changes. Estimated coefficients on foreign net PPE growth and foreign wage growth are similar to those obtained from regressions using the whole sample and presented in columns 1 and 3 of Table 2. Estimated effects of foreign changes on domestic activity in the instrumental variable regressions presented in columns 3 and 4 of Table 7 are likewise similar to those presented in columns 1 and 2 of Table 4 , the 0.3164 coefficient implying that 10 percent foreign investment is associated with 3.2 percent greater domestic investment, and the 0.4392 coefficient implying that 10 percent foreign wage growth is associated with 4.4 percent greater domestic wage growth.

A second issue that arises as a consequence of the empirical strategy is that reported estimates do not capture the effect of a domestic firm's initial expansion in markets abroad. Since the IV estimation method requires the use of beginning of period values of foreign activity, it is not possible to construct an instrument for new foreign investment by firms without prior foreign exposure. As the data in Appendix Table 1 illustrate, firms initiating activity abroad are responsible for only a small fraction of aggregate foreign investment, so their effect is unlikely to dominate the total responsiveness of domestic investment to foreign activities. It is also possible to analyze a subset of observations representing the first period following a firm's foreign entry. The regressions presented in columns 5-8 of Table 7 are run on this subsample of observations. Sample sizes are necessarily very small (351 and 347); nonetheless, the OLS results in columns 5

\footnotetext{
14 The BEA data identify purchases of one American multinational firm by another, and purchases of foreign affiliates previously owned by another firm in the BEA data.
} 
and 6 are similar to those reported in columns 1 and 2 of the same table for the considerably larger sample of firms that do not merge. Point estimates of the effects of foreign investment and foreign wage growth are larger in the IV specifications reported in columns 7 and 8, but are not statistically significant, owing to the small sample sizes. Thus, there is no indication that foreign expansion is associated with domestic contraction soon after firms initiate foreign activity.

\subsection{Other Domestic Activities}

Greater foreign production is likely to encourage firms to expand domestic activities that provide tangible and intangible inputs to foreign production. The regressions presented in Table 8 consider the effects of greater foreign sales on domestic research and development (R\&D) and domestic exports to affiliates located abroad. Columns 1 and 2 report estimated coefficients from regressions in which the dependent variable is the change in domestic R\&D. ${ }^{15}$ The 0.3631 estimated coefficient in the OLS regression reported in column 1 indicates that ten percent faster foreign sales growth is associated with 3.6 percent more rapid growth of domestic R\&D spending. In order to avoid bias that might arise due to the joint determination of domestic R\&D growth and foreign affiliate sales growth, the specification in column 2 instruments for foreign sales growth using foreign GDP growth rates. The 0.4931 estimated coefficient in this specification implies an even larger effect, ten percent faster foreign sales growth being associated with 4.9 percent greater domestic R\&D spending. Since foreign operations stand to benefit from intangible assets developed by $R \& D$ spending, it is not surprising that greater foreign investment might stimulate additional spending on R\&D in the United States.

Columns 3 and 4 report estimated coefficients from regressions in which the dependent variable is the growth in a parent company's exports to its affiliates. The estimated 0.6130 coefficient reported in column 3 indicates that ten percent higher growth of foreign sales is associated with 6.1 percent greater exports from U.S. parent companies to their foreign affiliates. The corresponding instrumental variables coefficient of 0.4940, reported in column four, is slightly smaller, but nonetheless indicates that firms whose initial investments were concentrated in economies that subsequently grew rapidly tend to expand their exports from the United States to affiliates abroad. These results are consistent with those presented in Table 4, in which 
domestic investment and wage growth respond positively to changes in their foreign counterparts.

\section{Implications}

The estimated relationship between foreign and domestic operations of American multinational firms carries direct implications for U.S. policies that influence levels of foreign investment by American companies. The United States taxes the foreign incomes of American firms, permitting taxpayers to claim tax credits for foreign income tax payments and to defer U.S. taxation of certain unrepatriated profits of foreign subsidiaries. There is controversy over the desirability of this tax regime, particularly when compared with the practice of many capitalexporting countries that exempt foreign income from taxation. A system of taxing foreign income while providing foreign tax credits is commonly justified by appeal to the principle of capital export neutrality, itself based on a model in which foreign investment reduces domestic investment on a one-for-one basis. Similar implications have been derived for monetary and commercial policies that influence exchange rates and world interest rates. Should the volume of domestic economic activity not fall in response to increased foreign investment, but instead rise, then policies that maximize national and world welfare look very different than they would if foreign and domestic business operations compete for the same costly resources. ${ }^{16}$ In particular, efficient policies in such an environment typically entail a more favorable stance toward outbound investment by American firms. Any such policy evaluation, however, rests on the reliability of estimated relationships between foreign and domestic activities.

Tables 4-8 present regressions that offer evidence that increases in foreign operations stimulate domestic economic activities during the 1982-1999 period. These effects of foreign operations on domestic sales and factor demands are identified by differences between firms in the growth rates of the foreign economies in which they invest, which in turn affect the rates at which firms expand their foreign investments. As a result, the estimates are cross-sectional in nature: they reflect comparisons of the subsequent domestic activities of firms that invested in certain foreign countries with firms that invested in others.

\footnotetext{
${ }^{15}$ Growth rates that serve as dependent variables in Table 8 are computed in the same way as other growth rates: they are ratios of changes between benchmark years to averages of beginning and end of period values.
} 
The domestic impact of policies that affect foreign investment levels of all American firms cannot be directly inferred from the reported estimates. The total domestic effects of such policies include price changes that affect all firms and are not reflected in cross-sectional comparisons of some firms with others. These general equilibrium considerations include changes in output prices of industries with significant foreign exposure, any endogenous effects on interest rates, exchange rates, wages, prices of investment goods, and others. These endogenous price changes are likely to attenuate, but not reverse in sign, the estimated firm-level effects of foreign operations on domestic sales, capital accumulation, employment, R\&D spending, and exports. In the absence of a complete general equilibrium analysis it is difficult to estimate the aggregate magnitudes of these effects on the U.S. economy, but there is nonetheless a presumption that aggregate effects resemble firm-level effects in sign, and may also be similar in magnitude.

\section{Conclusion}

Firms that expand their foreign operations simultaneously expand their domestic operations, and this relationship persists when actual foreign expansions are replaced by predicted values based on weighted growth rates of foreign economies. There is evidence that growing foreign investment is associated with growing domestic capital accumulation, employment, R\&D, and exports to related parties. While this firm-level evidence must be appropriately modified by general equilibrium considerations in evaluating aggregate policy effects, it nevertheless follows that greater foreign investment by individual American firms can be expected to stimulate additional domestic economic activity by the same firms.

This conclusion runs counter to the simple intuition that foreign direct investment represents a diversion of domestic economic activity by firms undertaking the foreign investment. The intuition is based on the notion that each firm has a fixed amount of global production, so additional foreign production comes at the cost of reduced domestic production. Neither firms nor economies operate on such a zero-sum basis, so there is ample reason to think that greater foreign production might be associated with greater demand for productive factors in the United States, and associated greater levels of activity. While there may be considerable

\footnotetext{
${ }^{16}$ The standard international tax theory is developed in Musgrave (1969) and Horst (1980), and reviewed by Gordon
} 
individual variation, the average experience of all American multinational firms over the last two decades is inconsistent with the simple story that foreign expansions come at the cost of reduced domestic activity.

and Hines (2002); Keen and Piekkola (1997), Hines (1999), and Desai and Hines (2003) offer recent critiques. 


\section{References}

Antràs, Pol (2003). "Firms, Contracts and Trade Structure.” Quarterly Journal of Economics 118 (4), 1375-1418.

Antràs, Pol and Elhanan Helpman (2004). “Global Sourcing.” Journal of Political Economy 112 (3), 552-591.

Blonigen, Bruce A. (2001). "In Search of Substitution between Foreign Production and Exports," Journal of International Economics 53:81-104.

Blonigen, Bruce A. and Wesley W. Wilson (1999). "Explaining Armington: What Determines Substitutability Between Home and Foreign Goods," Canadian Journal of Economics 32:1-21.

Brainard, S. Lael and David A. Riker (1997). “Are U.S. Multinationals Exporting Jobs?” NBER Working Paper No. 5958.

Davis, Steven J., R. Jason Faberman and John Haltiwanger (forthcoming). "The Flow Approach to Labor Markets: New Data Sources, Micro-Macro Links and the Recent Downturn.” Journal of Economic Perspectives.

Davis, Steven J., John C. Haltiwanger, and Scott Schuh (1996). Job Creation and Destruction, (Cambridge, MIT Press).

Desai, Mihir A., C. Fritz Foley and James R. Hines Jr. (2004). "The Costs of Shared Ownership: Evidence from International Joint Ventures.” Journal of Financial Economics 73 (2), 323-374.

Desai, Mihir A., C. Fritz Foley and James R. Hines Jr. (Forthcoming). "Foreign Direct Investment and the Domestic Capital Stock." American Economic Review Papers and Proceedings.

Desai, Mihir A. and James R. Hines Jr. (2003). “Evaluating International Tax Reform.” National Tax Journal 56 (3), 487-502.

Devereux, Michael P. and Harold Freeman (1995). "The Impact of Tax on Foreign Direct Investment: Empirical Evidence and the Implications for Tax Integration Schemes.” International Tax and Public Finance 2 (1), 85-106.

Feenstra, Robert C. and Gordon H. Hanson (1996). "Globalization, Outsourcing and Wage Inequality.” American Economic Review 86 (2), 240-245.

Feenstra, Robert C. and Gordon H. Hanson (1999). "The Impact of Outsourcing and HighTechnology Capital on Wages: Estimates for the U.S. 1979-1990.” Quarterly Journal of Economics 114 (3), 907-940. 
Feenstra, Robert C. and Gordon H. Hanson (2005). "Ownership and Control in Outsourcing to China: Estimating the Property-Rights Theory of the Firm.” Quarterly Journal of Economics 120 (2), 729-761.

Feldstein, Martin (1995). “The Effects of Outbound Foreign Direct Investment on the Domestic Capital Stock.” In Martin Feldstein, James R. Hines Jr. and R. Glenn Hubbard (eds.), The Effects of Taxation on Multinational Corporations (Chicago: University of Chicago Press), 43-63.

Gordon, Roger H. and James R. Hines Jr. (2002). “International Taxation.” In Alan J. Auerbach and Martin Feldstein (eds.), Handbook of Public Economics, vol. 4 (Amsterdam: NorthHolland), 1935-1995.

Hanson, Gordon H., Raymond Mataloni and Matthew J. Slaughter. (Forthcoming). "Vertical Production Networks in Multinational Firms.” Review of Economics and Statistics.

Harrison, Anne E. and Margaret S. McMillan (2004). “The Impact of Overseas Investment by U.S. Multinationals on Wages and Employment.” Working Paper.

Helpman, Elhanan (1984). “A Simple Theory of International Trade with Multinational Corporations.” Journal of Political Economy 92 (3), 451-71.

Helpman, Elhanan, Mark Melitz, and Stephen Yeaple (2004). "Export Versus FDI with Heterogeneous Firms,” American Economic Review 94 (1), 300-316.

Heston, Alan, Robert Summers and Bettina Aten (2002). Penn World Table Version 6.1 (Philadelphia: Center for International Comparisons at the University of Pennsylvania).

Hines, James R., Jr. (1999). “The Case against Deferral: A Deferential Reconsideration.” National Tax Journal 52 (3), 385-404.

Hines, James R., Jr. (2005). “Do Tax Havens Flourish?” In James M. Poterba (ed.), Tax Policy and the Economy, vol. 19 (Cambridge, MA: MIT Press), 65-99.

Horst, Thomas (1980). “A Note on the Optimal Taxation of International Investment Income.” Quarterly Journal of Economics 94 (4), 793-798.

Hummels, David, Jun Ishii and Kei-Mu Yi (2001). "The Nature and Growth of Vertical Specialization in World Trade.” Journal of International Economics 54 (1), 75-96.

Keen, Michael and Hannu Piekkola (1997). "Simple Rules for the Optimal Taxation of International Capital Income.” Scandinavian Journal of Economics 99 (3), 447-461.

Lipsey, Robert E. (1995). “Outward Direct Investment and the U.S. Economy.” In Martin Feldstein, James R. Hines Jr. and R. Glenn Hubbard (eds.), The Effects of Taxation on Multinational Corporations (Chicago: University of Chicago Press), 7-33.

Markusen, James R. (1984). "Multinational Firms, Multiplant Economies and Gains from Trade,” Journal of International Economics 16 (1), 205-226. 
Markusen, James R. (2002). Multinational Firms and the Theory of International Trade (Cambridge: MIT Press).

Musgrave, Peggy B. (1969). United States Taxation of Foreign Investment Income: Issues and Arguments (Cambridge, MA: International Tax Program, Harvard Law School).

Riker, David A. and S. Lael Brainard. 1997. "U.S. Multinationals and Competition from LowWage Countries.” NBER Working Paper No. 5959.

Samuelson, Paul A. (1974). "Complementarity: An Essay on the $40^{\text {th }}$ Anniversary of the HicksAllen Revolution in Demand Theory.” Journal of Economic Literature 12 (4): 12551289.

Slaughter, Matthew (2000). "Production Transfer within Multinational Enterprises and American Wages,” Journal of International Economics 50 (2), 449-472.

Stevens, Guy V.G. and Robert E. Lipsey (1992). "Interactions Between Domestic and Foreign Investment.” Journal of International Money and Finance 11 (1), 40-62.

Tornqvist, Leo, Pentti Vartia, and Yrjo O. Vartia. (1985). "How Should Relative Changes Be Measured?" American Statistician 39 (1): 43-46.

Yi, Kei-Mu (2003). “Can Vertical Specialization Explain the Growth of World Trade?” Journal of Political Economy 111 (1), 52-103. 
Figure 1: Domestic and Foreign Sales Growth of Multinational Firms, 1982-1999

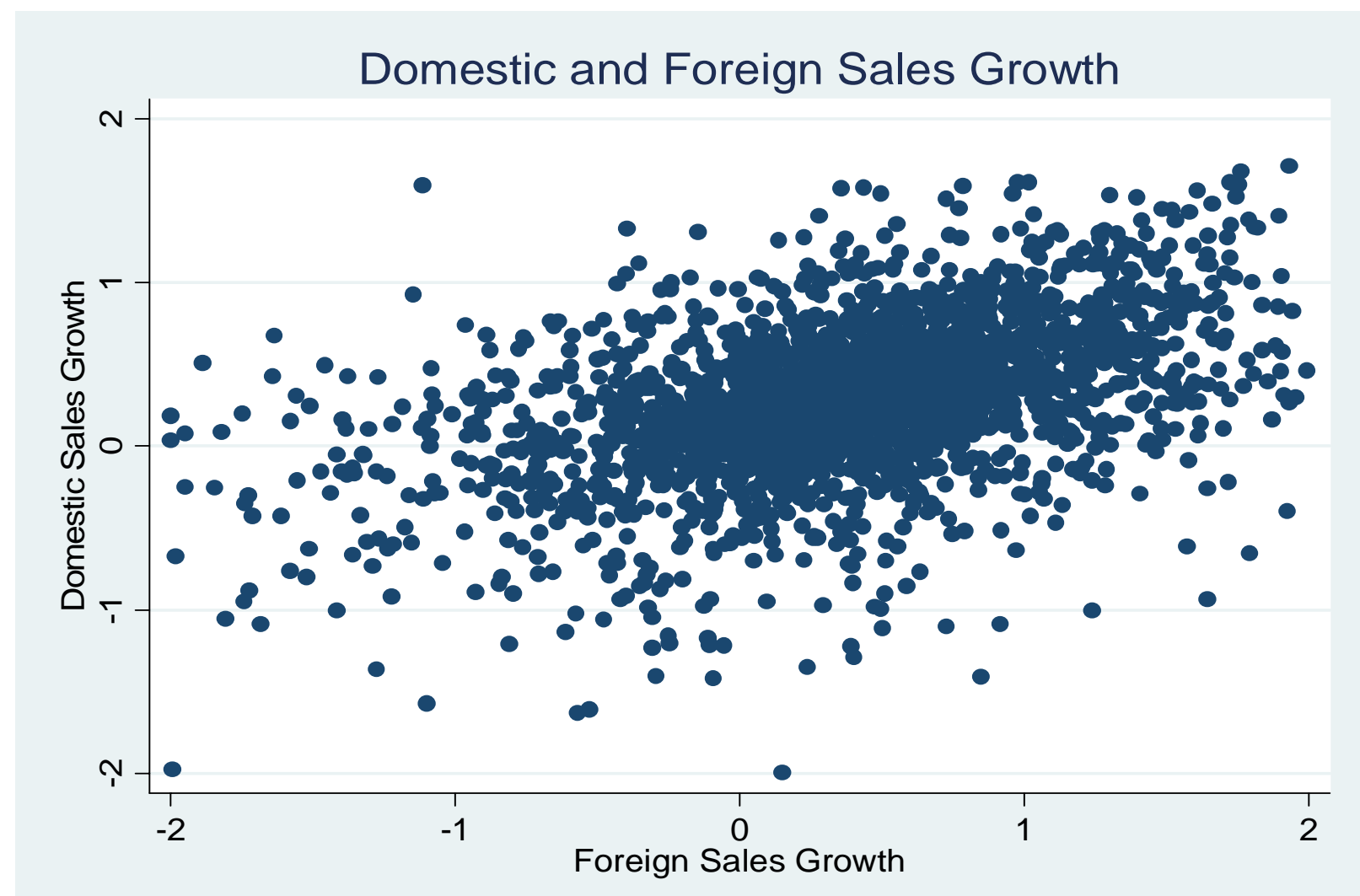

Note: The vertical and horizontal axes of the figure measure growth rates of domestic sales and foreign sales. Growth rates are defined as ratios of changes in sales to averages of beginning and ending period values. Each observation is a single multinational firm between two benchmark years, the benchmark years consisting of 1982, 1989, 1994 and 1999. 


\begin{tabular}{|c|c|c|c|}
\hline & $\underline{\text { Mean }}$ & $\underline{\text { Median }}$ & $\begin{array}{l}\text { Standard } \\
\text { Deviation }\end{array}$ \\
\hline Foreign Affiliate Asset Growth & 0.4119 & 0.4284 & 0.6775 \\
\hline Foreign Affiliate Net PPE Growth & 0.3507 & 0.3749 & 0.7876 \\
\hline Foreign Affiliate Employment Compensation Growth & 0.3417 & 0.3668 & 0.6957 \\
\hline Foreign Affiliate Employment Growth & 0.1341 & 0.1221 & 0.6995 \\
\hline Foreign Affiliate Sales Growth & 0.3707 & 0.3864 & 0.6518 \\
\hline Parent Weighted GDP Growth Rate & 0.2495 & 0.2118 & 0.1187 \\
\hline Domestic Asset Growth & 0.3238 & 0.3204 & 0.5401 \\
\hline Domestic Net PPE Growth & 0.1569 & 0.1612 & 0.9520 \\
\hline Domestic Employment Compensation Growth & 0.2407 & 0.2570 & 0.4892 \\
\hline Domestic Employment Growth & 0.0193 & 0.0284 & 0.4720 \\
\hline Domestic Sales Growth & 0.2803 & 0.2857 & 0.4596 \\
\hline Foreign Affiliate Net PPE Growth (Levels) & 129,666 & 3,516 & $1,129,607$ \\
\hline Foreign Affiliate Employment Compensation Growth (Levels) & 40,541 & 4,622 & 247,635 \\
\hline Domestic Net PPE Growth (Levels) & 113,839 & 9,996 & $3,995,837$ \\
\hline Domestic Employment Compensation Growth (Levels) & 82,321 & 18,887 & 566,158 \\
\hline Parent R\&D Growth & 0.2450 & 0.3373 & 0.9206 \\
\hline Growth of Parent Exports to Affiliates & 0.2618 & 0.4083 & 1.0896 \\
\hline GDP Growth Weighted by Parent Trade & 0.2346 & 0.1995 & 0.1102 \\
\hline Change in Real Exchange Rate & -0.0328 & -0.0497 & 0.1175 \\
\hline
\end{tabular}

Notes: Growth rates of assets, net property, plant and equipment (PPE), employment compensation, employment, and sales are computed as the ratios of changes in activity between benchmark years to averages of beginning and ending year levels of activity. Parent Weighted GDP growth rate is the weighted change, between benchmark years, in the per capita gross domestic product of affiliate host countries, divided by the average of beginning and ending period values. GDP data are drawn from Heston, Summers, and Aten (2002). Country weights used for each parent equal beginning of period local net PPE levels. Growth measures based on levels are unscaled weighted changes in activity. Growth rates of parent research and development, and parent exports to affiliates, are ratios of changes between benchmark years to average values of these measures in the benchmark years. GDP growth weighted by Parent Trade is calculated using weights equal to beginning of period parent exports to unrelated parties. Changes in real exchange rates are weighted changes, equal to the ratio of the change in the beginning and end of period real host country U.S. dollar exchange rate to the average of this rate at the beginning and end of the period, using weights equal to start of period PPE. Real exchange rates are calculated using nominal exchange rates reported in Heston, Summers, and Aten (2002) and measures of inflation from the IMF International Financial Statistics database. 
Table 2

\section{Changes in Foreign and Domestic Activity: OLS Specifications}

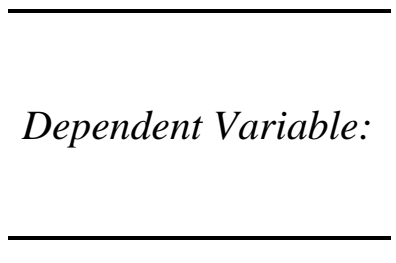

Constant

Foreign Net PPE

Growth

Foreign Asset Growth

Foreign Employment

Compensation

Growth

Foreign Employment

Growth

Foreign Sales Growth

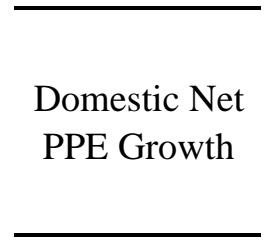

(1)

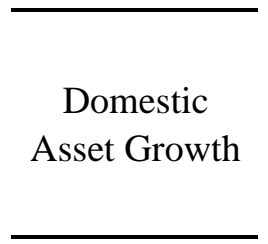

(2)

1.0659

(0.0202)

0.1994

(0.0166)

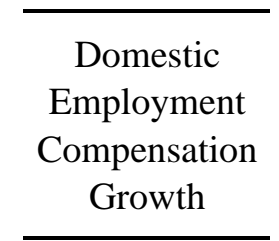

(3)

0.1773
$(0.0206)$

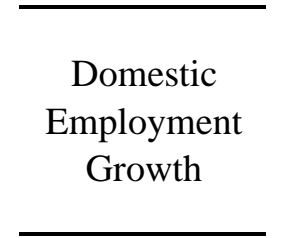

(4)

$-0.0122$

(0.0186)
Domestic Sales

Growth
(5)

0.1654

(0.0168)
0.2953

(0.0181)
0.2581

(0.0166)
0.2448

(0.0160)
0.3181

(0.0166)

No. of Obs.

2,286

2,420

2,282

0.1847

0.1438

R-Squared

0.7275

0.1450

0.2254

Note: The dependent variables are domestic growth rates of net property, plant and equipment (PPE) (column 1), assets (column 2), employment compensation (column 3), employment (column 4), and sales (column 5). Domestic and foreign growth rates are ratios of changes in activity between benchmark years to averages of the beginning and end of period values. All regressions are OLS specifications that include period fixed effects. Heteroskedasticity-consistent standard errors that correct for clustering at the parent level appear in parentheses. 
Table 3

\section{Foreign GDP Growth and Changes in Foreign Operations}

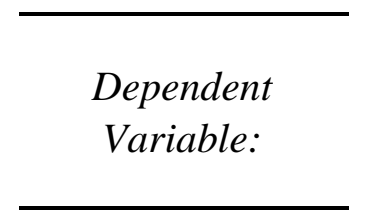

Constant

Parent Weighted

GDP Growth Rate

\begin{tabular}{l}
\hline Foreign Net \\
PPE Growth \\
\hline
\end{tabular}

(1)

$$
\begin{array}{r}
-0.1764 \\
(0.1236)
\end{array}
$$

1.7802

(0.2911)

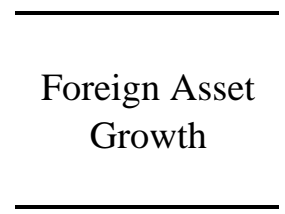

(2)

$$
\begin{array}{r}
0.1199 \\
(0.0550)
\end{array}
$$

1.4721

$(0.2572)$

\begin{tabular}{c}
\hline Foreign \\
Employment \\
Compensation \\
Growth \\
\hline
\end{tabular}

(3)

$$
\begin{array}{r}
0.0384 \\
(0.1190)
\end{array}
$$

1.2356

(0.2799)

Foreign
Employment
Growth

(4)

$-0.0772$

$(0.1114)$

0.6965

$(0.2623)$
Foreign Sales

Growth
(5)

0.0493

(0.0500)

1.5797

(0.2298)

No. of Obs.

Note: The dependent variables are foreign growth rates of net property, plant and equipment (PPE) (column 1), assets (column 2), employment compensation growth (column 3), employment growth (column 4), and sales (column 5). Foreign growth rates are ratios of changes in activity between benchmark years to averages of the beginning and end of period values. Parent Weighted GDP growth rates are the weighted changes, between benchmark periods, in per capita gross domestic products of affiliate host countries, divided by averages of beginning and end of period values. GDP data are drawn from Heston, Summers, and Aten (2002). Weights equal parent beginning of period net property plant and equipment in each country. All regressions are OLS specifications that include period fixed effects. Heteroskedasticity-consistent standard errors that correct for clustering at the parent level appear in parentheses. 


\section{Table 4}

\section{Effects of Foreign Operations on Domestic Activity: IV Specifications}

$\overline{\text { Dependent Variable: }}$

Constant

Foreign Net PPE

Growth (Rates/Levels)

Foreign Employment

Compensation Growth

(Rates/Levels)

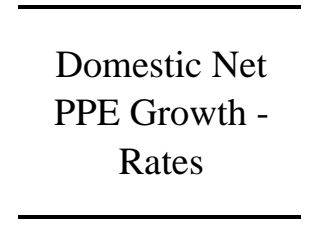

(1)

0.2701

(0.0386)

0.2174

(0.1010)

\begin{tabular}{c}
\hline Domestic \\
Employment \\
Compensation \\
Growth - Rates \\
\hline
\end{tabular}

(2)

0.1372

(0.0443)

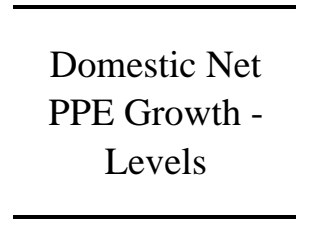

(3)

5912.1940

(64421.7200)

0.6720

(0.3087)

\begin{tabular}{c}
\hline Domestic \\
Employment \\
Compensation \\
Growth - Levels \\
\hline
\end{tabular}

(4)

50341.9400

(25279.1100)

No. of Obs.

Note: The dependent variable in column 1 is growth of domestic property, plant and equipment (PPE), and the dependent variable in column 2 is growth of domestic employment compensation. Domestic and foreign growth rates are defined as ratios of changes in activity between benchmark years to averages of the beginning and end of period values. The dependent variable in column 3 is the change in domestic net PPE between benchmark years, and the dependent variable in column 4 is the change in domestic employment compensation. Independent variables are corresponding foreign changes, measured as growth rates in columns 1 and 2, and as level changes in columns 3 and 4. All regressions are IV specifications in which parent weighed GDP growth rates are used as instruments for foreign growth rates or changes in levels. In the first two columns, instruments are calculated by first computing GDP growth rates measured as the change in host country GDP per capita in between benchmark years scaled by average GDP per capita at the beginning and end of the period. Values of per capita gross domestic product are taken from Heston, Summers, and Aten (2002). These GDP growth rates are then weighted using weights equal to the beginning of period net property, plant and equipment in a country. Instruments used in the regressions reported in columns 3 and 4 equal the instruments used in the regressions reported in columns 1 and 2, multiplied by beginning of period foreign PPE (column 3) and beginning of period foreign employment compensation (column 4). All specifications include period fixed effects. Heteroskedasticity-consistent standard errors that correct for clustering at the parent level appear in parentheses 
Table 5

\section{Alternative Instruments and Industry Controls}

$\overline{\text { Dependent Variable: }}$

Constant

Foreign Net PPE Growth

Foreign Employment

Compensation Growth

Period Fixed Effects?

Period/Industry Fixed

Effects?

IV w/ Parent Weighted GDP

Growth?

IV w/ Parent Weighted GDP

Growth Residuals?

No. of Obs.

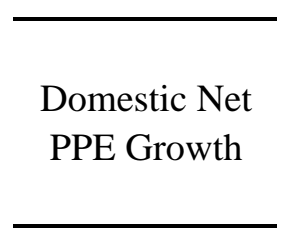

(1)

0.2714

$(0.0392)$

0.2132

(0.1032)

\begin{tabular}{c}
\hline Domestic \\
Employment \\
Compensation \\
Growth \\
\hline
\end{tabular}

(2)

0.1385

(0.0429)

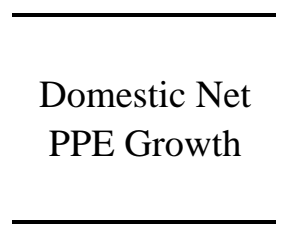

(3)

1.0020

(0.0159)

0.2560

(0.1037)

\begin{tabular}{c}
\hline Domestic \\
Employment \\
Compensation \\
Growth \\
\hline
\end{tabular}

(4)

0.1623

(0.0780)
0.3999

0.3948

(0.1405)

Y

Y

N

$\mathrm{N}$

N

N

Y

Y

N

N

Y

Y

Y

Y

N

$\mathrm{N}$ 2,286

Note: The dependent variables are domestic growth rates of net property, plant and equipment (PPE) (columns 1 and 3) and growth rates of domestic employment compensation (columns 2 and 4). Domestic and foreign growth rates are ratios of changes in activity between benchmark years to the average of the beginning and end of period values. All regressions are IV specifications. Parent weighed measures of host country GDP growth are used as instruments for foreign affiliate growth. Instruments in the first and second columns equal residuals from regressions of GDP growth rates on its own lag, with these residuals then weighted by beginning of period PPE.

Instruments in columns 3 and 4 weight host country GDP by beginning of period net PPE. The specifications in columns 1 and 2 include period fixed effects and the specifications in columns 3 and 4 include separate fixed effects for each 2-digit industry in each period. Heteroskedasticity-consistent standard errors that correct for clustering at the parent level appear in parentheses. 
Table 6

\section{Introducing Controls for Trade Patterns and Exchange Rates}

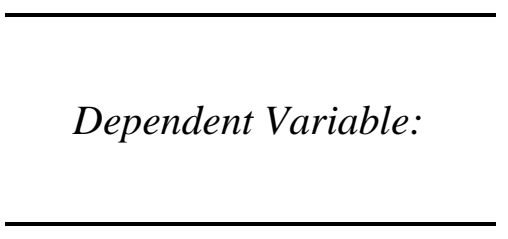

Constant

Foreign Net PPE Growth

Foreign Employment

Compensation Growth

GDP Growth Weighted by

Parent Trade

Change in Real Exchange

Rate

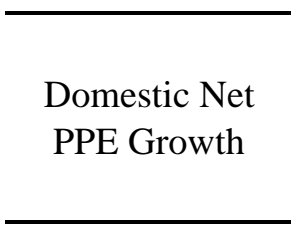

(1)

0.2518

$(0.0442)$

0.2583

(0.1104)

\begin{tabular}{c}
\hline Domestic \\
Employment \\
Compensation \\
Growth \\
\hline
\end{tabular}

(2)

0.0964

(0.0802)

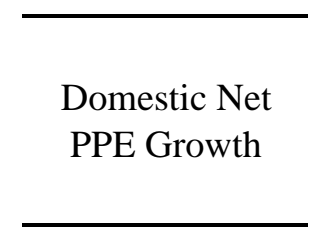

(3)

1.0373

(0.0694)

0.3479

(0.1635)

\begin{tabular}{c}
\hline Domestic \\
Employment \\
Compensation \\
Growth \\
\hline
\end{tabular}

(4)

0.0977

(0.0766)
0.3849

0.4855

(0.1370)

0.0451

$-0.0122$

0.0223

(0.1435)

(0.1330)

$-0.0673$

(0.1268)

0.5051

0.2522

(0.2795)

(0.3132)

No. of Obs.

Note: The dependent variables are domestic growth rates of net property, plant and equipment (PPE) (columns 1 and 3), and employment compensation (columns 2 and 4). Domestic and foreign growth rates are ratios of changes in activity between benchmark years to averages of beginning and end of period values. All regressions are IV specifications and include period fixed effects. Parent weighed GDP growth rates are used as instruments for foreign growth rates. Instrumental variables are calculated by first computing GDP growth rates measured as the change in host country GDP per capita between benchmark years scaled by average GDP per capita at the beginning and end of the period. Values of per capita gross domestic product are taken from Heston, Summers, and Aten (2002). These GDP growth rates are then weighted by beginning of period net PPE. Changes in the real exchange rate equal ratios of changes in the beginning and end of period real host country U.S. dollar exchange rates to average values at the beginning and end of the period, weighted by beginning of period affiliate PPE. Real host country U.S. dollar exchange rates are computed using nominal exchange rates taken from Heston, Summers, and Aten (2002), and inflation is drawn from the IMF International Financial Statistics database. GDP Growth Weighted by Parent Trade is the weighted average of GDP growth rates, computed using weights equal to beginning of period parent exports to unrelated parties in a country. Heteroskedasticity-consistent standard errors that correct for clustering at the parent level appear in parentheses. 
Table 7

Controlling for Mergers and New Entrants

\begin{tabular}{c}
\hline Dependent \\
Variable:
\end{tabular}

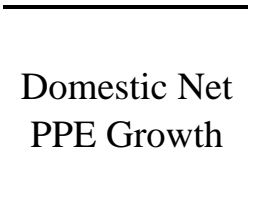

(1)

Constant

1.0918

(0.0583)

0.1745

(0.0190)

Growth

Foreign Employment

Compensation

Growth

\section{GDP Growth}

Weighted by Parent

Trade

Change in Real

Exchange Rate

IV w/ Parent

Weighted GDP

Growth?

Drop Acquirers?

Focus on New

Entrants?

No. of Obs.

R-Squared

0.0722

(0.1691)

$\mathrm{N}$

Y

N

0.7427

Pr

Domestic Net
PPE Growth

\begin{tabular}{c} 
Domestic \\
Employment \\
Compensation \\
Growth \\
\hline
\end{tabular}

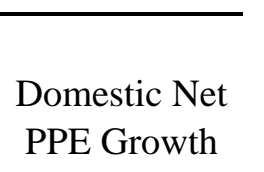

Domestic

Compensation

Growth

Growth

(4)

\subsection{0}

(0.0325)

(3)

0.2214

(0.0623)

0.1069

(0.0646)

(5)

0.3731

(0.1007)

0.3164

0.1383

(0.1498)

(0.0394)

0.4392

(0.1890)

(0.0194)

(0.1339)

0.0484

0.0379

(0.1424)

$-0.0075$

(0.1567)

0.4906

(0.2673)

0.2087
$(0.2841)$

(0.1543)

N

Y

$\mathrm{Y}$

Y

Y

0.1667

(0.4875)

(6)

0.2843

(0.0794)

Domestic Net
PPE Growth

Domestic

Employment

Compensation

Growth

(8)

(7)

0.0247

$-0.0956$

(0.2899)

(0.2821)

0.8700

(0.4948)

0.1888

(0.0338)

0.8732

$-0.0979$

0.0230

(0.3559)

$-0.1910$

(0.6962)

(0.5496)

1.0780

0.4097

(0.2731)

1.7792

(0.6868)

1.1938

(0.6823)

N

N

N

1,530

0.1291

1,535
$\mathrm{N}$

N

Y

(0.3355)

N

N

Y

351

0.4734
Y

$\mathrm{N}$

Y

Y

$\mathrm{Y}$

$\mathrm{N}$

347

Note: The dependent variables are domestic growth rates of net property, plant and equipment (PPE) (columns 1, 3, 5 and 7) and growh of domestic employment compensation (columns 2, 4, 6, and 8). Domestic and foreign growth rates are ratios of changes in activity between benchmark years to averages of beginning and end of period values. The regressions in columns 1, 2, 5 and 6 are OLS specifications and the regressions in columns 3, 4, 7 and 8 are IV specifications. Parent weighed GDP growth rates are used as instruments for foreign growth rates. Instrumental variables are calculated by first computing GDP growth rates measured as the change in host country GDP per capita between benchmark years scaled by average GDP per capita at the beginning and end of the period. Values of per capita gross domestic product are taken from Heston, Summers, and Aten (2002). GDP growth rates are weighted by beginning of period net PPE. Changes in real exchange rates equal ratios of changes in beginning and end of period real host country U.S. dollar exchange rates to averages at the beginning and end of the period, weighted by beginning of period affiliate PPE. Real host country U.S. dollar exchange rates are computed using nominal exchange rates taken from Heston, Summers, and Aten (2002) and measures of inflation from the IMF International Financial Statistics database. GDP Growth Weighted by Parent Trade is the weigted average of GDP growth rates, computed using weights equal to beginning of period parent exports to unrelated parties in a country. The sample is restricted to non-acquirers in columns 1-4 and to new entrants in columns 5-8. Heteroskedasticity-consistent standard errors that correct for clustering at the parent level appear in parentheses. 


\section{Table 8}

\section{Foreign Growth, Domestic R\&D, and Domestic Exports}

\begin{tabular}{c}
\hline $\begin{array}{c}\text { Dependent } \\
\text { Variable: }\end{array}$ \\
\hline
\end{tabular}

\begin{tabular}{c}
\hline $\begin{array}{c}\text { Parent R\&D } \\
\text { Growth }\end{array}$ \\
\hline
\end{tabular}

(1)

\begin{abstract}
Constant
\end{abstract}
Foreign Sales

Growth

\section{IV w/ Parent \\ Weighted GDP \\ Growth?}

No. of Obs.

R-Squared
$\mathrm{N}$

2,095

0.1135

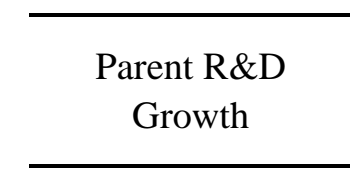

(2)

1.0963

$(0.2084)$

$(0.0325)$

0.3631

(0.0341)

0.4931

(0.2185)

\begin{tabular}{c}
\hline Growth of Parent \\
Exports to \\
Affiliates \\
\hline
\end{tabular}

(3)

1.7618

(0.0146)
0.6130

(0.0406)

\begin{tabular}{c}
\hline Growth of Parent \\
Exports to \\
Affiliates \\
\hline
\end{tabular}

(4)

1.8047

(0.0888)

0.4940

(0.2464)
Y

2,095
$\mathrm{N}$

2,278

0.1654

Note: The dependent variables are the growth rate of parent R\&D expenditures (columns 1 and 2) and parent exports to affiliates (columns 3 and 4). Growth rates are computed by taking ratios of changes in measures between benchmark years to averages of beginning and end of period values. The regressions in columns 1 and 3 are OLS specifications, and the regressions in columns 2 and 4 are IV specifications. Weighed measures of host country GDP growth are used as instruments for foreign affiliate sales growth in columns 2 and 4 . Instruments are calculated by first computing GDP growth rates measured as changes in host country GDP per capita between benchmark years scaled by average GDP per capita at the beginning and end of the period. Values of per capita gross domestic product are taken from Heston, Summers, and Aten (2002). GDP growth rates are weighted by beginning of period affiliate PPE. All specifications include period/industry fixed effects. Heteroskedasticity-consistent standard errors that correct for clustering at the parent level appear in parentheses. 


\section{Appendix Table 1 \\ Changes in Aggregate Foreign Property, Plant and Equipment}

\begin{tabular}{l} 
Total Change \\
\cline { 2 - 3 } \\
\cline { 2 - 2 }
\end{tabular}




\section{Appendix Table 2}

\section{Foreign GDP Growth and Foreign Sales by Destination}

\begin{tabular}{c}
\hline Dependent \\
Variable:
\end{tabular}

Constant

\begin{tabular}{c}
\hline Growth in \\
Affiliate Local \\
Sales \\
\hline
\end{tabular}

(1)

\begin{tabular}{c}
\hline Growth in \\
Affiliate Sales \\
Outside of Host \\
Country \\
\hline
\end{tabular}

(2)

0.0770

(0.1618)

$-0.0875$

$(0.1434)$

$$
1.7577
$$

\begin{tabular}{c}
\hline Growth in \\
Affiliate Sales \\
to Unrelated \\
Parties \\
\hline
\end{tabular}

(3)

$-0.0603$

(0.1289)

1.6313

(0.3034)

\begin{tabular}{c}
\hline Growth in \\
Affiliate Sales \\
to Related \\
Parties \\
\hline
\end{tabular}

(4)

$-0.1158$

(0.1036)

1.0964

(0.4586)

No. of Obs.

Note: The dependent variables are growth rates of affiliate local sales in the affiliate's host country (column 1), affiliate sales outside of the affiliate's host country (column 2), affiliate sales to unrelated parties (column 3), and affiliate sales to related parties (column 4). Growth rates are ratios of changes in activity between benchmark years to averages of the beginning and end of period values. Parent Weighted GDP growth rates are weighted changes, between benchmark periods, in per capita gross domestic product of affiliate host countries, divided by averages of beginning and end of period values. GDP data are drawn from Heston, Summers, and Aten (2002). Weights equal parent beginning of period net property plant and equipment in each country. All regressions are OLS specifications that include period fixed effects. Heteroskedasticity-consistent standard errors that correct for clustering at the parent level appear in parentheses. 


\section{Appendix Table 3}

\section{Sales Destinations and the Effect of Foreign GDP Growth on Foreign Operations}

$\begin{array}{lll}\text { Dependent Variable: } & & \text { Foreign Net } \\ \text { PPE Growth }\end{array}$

Constant

Parent Weighted GDP

Growth Rate

High Local Sales Dummy

High Local Sales Dummy

* Parent Weighted GDP

Growth Rate

High Related Sales

Dummy

High Related Sales

Dummy * Parent Weighted

GDP Growth Rate
(1)

\begin{tabular}{c}
\hline Foreign \\
Employment \\
Compensation \\
Growth \\
\hline
\end{tabular}

(2)

$-0.2345$

(0.1289)

1.9034

(0.3106)

0.1276

(0.0780)

$-0.2985$

(0.2825)
$-0.0914$

(0.1293)

1.5488

(0.3100)

0.1311

(0.0701)
$-0.3349$

(0.2580)

\begin{tabular}{l}
\hline Foreign Net \\
PPE Growth \\
\hline
\end{tabular}

(3)

$-0.1037$

(0.1272)

1.5932

(0.3282)

\begin{tabular}{c}
\hline Foreign \\
Employment \\
Compensation \\
Growth \\
\hline
\end{tabular}

(4)

0.0431

(0.1275)

1.2841

(0.3189)

No. of Obs.

2,224

2,225

2,224

2,225

R-Squared

0.0488

0.0519

0.0487

0.0556

\footnotetext{
Note: The dependent variables are foreign growth rates of net property, plant and equipment (PPE) (columns 1 and 2) and employment compensation (columns 3 and 4). Foreign growth rates are ratios of changes in activity between benchmark years to averages of the beginning and end of period values. Parent Weighted GDP growth rates are weighted changes, between benchmark periods, in per capita gross domestic product of affiliate host countries, divided by averages of beginning and end of period values. The High Local Sales Dummy equals one for parent companies whose foreign affiliates sell above-median fractions of their output to local host country markets, and is zero otherwise. The High Related Sales Dummy is equals one for parent companies whose foreign affiliates sell abovemedian fractions of their output to related parties, and is zero otherwise. GDP data are drawn from Heston, Summers, and Aten (2002). Weights equal parent beginning of period net property plant and equipment in each country. All regressions are OLS specifications that include period fixed effects. Heteroskedasticity-consistent standard errors that correct for clustering at the parent level appear in parentheses.
} 


\section{Appendix Table 4}

\section{Effects of Foreign Operations on Domestic Assets, Employment, and Sales}

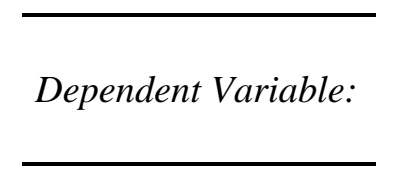

\begin{tabular}{c}
\hline Domestic \\
Asset Growth \\
\hline
\end{tabular}

(1)

Constant

0.2658

(0.0477)

0.2431

(0.1111)

Foreign Asset

Growth

Foreign

Employment

Growth

Foreign Sales

Growth

Period Fixed

Effects?

Period/Industry

Fixed Effects?

IV w/ Parent

Weighted GDP

Growth?

IV w/ Parent

Weighted GDP

Growth Residuals?

$\mathrm{N}$

Y

Y

Y

$\mathrm{N}$

$\mathrm{N}$

2,429

0.1747
$(0.0339)$

$-0.0112$

(0.0549)

0.4892

(0.2454)

0.2920

(0.0877)

No. of Obs.

2,420

2,274

Y

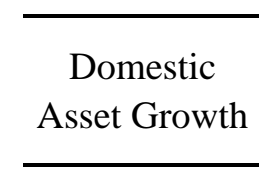

(4)

0.5772

(0.2560)

\begin{tabular}{c}
\hline Domestic \\
Employment \\
Growth \\
\hline
\end{tabular}

(5)

$-0.0135$

(0.0050)

0.2818

(0.1116)

\section{Domestic Sales Growth}

(6)

\subsection{3}

(0.0333)

Y

Y

0.6314

(0.2644)

\footnotetext{
Note: The dependent variables are domestic growth rates of assets (columns 1 and 4), employment (columns 2 and 5) and sales (columns 3 and 6). Domestic and foreign growth rates are ratios of changes in activity between benchmark years to averages of beginning and end of period values. All regressions are IV specifications. Instruments in columns one through three weight host country GDP growth rates by beginning of period PPE. Instruments in the last three columns are residuals from regressions of GDP growth rates on its own lag, weighted by beginning of period PPE. The specifications in columns 1-3 include period fixed effects and the specifications in columns 4-6 include period/industry fixed effects. Heteroskedasticityconsistent standard errors that correct for clustering at the parent level appear in parentheses.
} 